\title{
PENELITIAN PEMANFAATAN KULIT ITIK
}

\section{Oleh : Sri Untari *, Widari *, Emiliana K *, Ani Lasmini **}

\section{ABSTRACT}

Study on utilization of duck skins was intended to identify the right method of obtaining duck skins which could be utilized as maximum as posible, and it was conducted among others by observing the method of depilating feathers and obtaining quality duck skins. 24 duck of confine and tended were used in this study, and ther were 3 treat ments provided on the duck skins i.c : feasher depilation, no feather depilation and depilation using ash. The results of the study showed that the re were no significant between tended and confine duck skins $(P \leq 0,05)$ on- the test results of tensile strength. On visual inspection of no depilated duck skins showed there was only $1 \%$ damage occured, but the feather coul be not be utilized, while $5 \%$ damage occured on the depilated duck skins, hut the feather could be not be utilized. It was suggested that the feather of the duck skins should be depilated hefore processing.

\section{N T ISARI}

Yang dimaksud dengan Penclitian Pemanfaatan Kulit ltik ini ialah penelitian untuk mendapatkan kulit itik yang dapat dimanfaatkan semaksimal mungkin antara lain dengan penelitian cara pencabutan bulu yang baik. Penelitian ini menggunakan sampel 24 ckor itik yang terdiri dari itik terkurung dan itik gembala dengan 3 perlakuan yaitu : dicabut bulunya, tanpa dicabut bulu dan dicabut hulu dengan abu gosok sebagai bahan pembantu. Hasil penelitian menunjukkan bahwa tidak ada heda nyata antara cara pencabutan bulu $(P \leq 0,05)$ pada hasil uji kekuatan tarik. Pada uji organoleptis kulit yang dicabut bulunya sebelum diproses kerusakan kulitnya $5 \%$ dan bulunya dapat dimanfaatkan. Disarankan agar dalam pemanfaatkan kulit itik sebaiknya dilakukan pencabutan bulu sebelum diproses.

* Peneliti pada Balai Besar Penelitian dan Pengembangan Industri Barang Kulit , Karet dan Plastik, Yogyakarta.

* Peneliti pada Balai Penelitian Ternak, Ciawi, Bogor. 


\section{PENDAIIULUAN}

Industri perkulitan di Indonesia saat ini dihadapkan pada dua tantangan tama yaitu usaha peningkatan penggunaan kulit-kulit konvensional (sapi, ker au, domba dan kambing) dan yang kedua usaha mencari sumber-sumber kulit entah lainnya yang mempunyai motif yang unik dan spesifik (Koentoro, $\mathrm{S}$, 99()$)$.

Dalam usaha untuk memenuhi kebutuhan Industri kulit, dimana bahan aku yang tersedia masih sangat terbatas (Djojowidagdo S, 1988), oleh karena u kulit lainnya mulai diangkat kepermukaan dunia perkulitan seperti itik dan in-lain untuk menutupi kebutuhan kulit yang konvensional (Koentoro $\mathrm{S}$, 990). Kulit itik mempunyai rajah yang khas yaitu berbentuk menyerupai rajah urung Onta ("Ostrick") (Bambang Oetojo, 1990).

Menurut Untari, 1990, kulit itik yang disamak dengan bahan penyamak om memungkinkan dapat digunakan untuk kulit sarung tangan golf. Untuk endapatkan luasan yang maksimal dari kulit itik maka cara pembelahan pada aktu pengulitan dilakukan dengan belah punggung. Dengan pembelahan terbut akan didapatkan luas kulit itik yang berajah khas maksimal (Untari S, ()). Disamping itu rajah yang khas didapatkan pada bekas bulu, bagian yang nyak ditumbuhi bulu adalah di bagian perut. Tetapi proses pencabutan bulu alah merupakan hal yang sulit, karena bila tidak dilakukan dengan hati-hati an menimbulkan kerusakan kulit atau sobek (Untari S, 1990). Untuk mengndari hal tersebut diatas maka dilakukan penelitian untuk dapat memanfaatn kulit itik semaksimal mungkin, dalam arti kulit tidak banyak yang rusak dan ah yang khas pada luas-an maksimal.

Dalam Penelitian diterapkan 3 (tiga) perlakuan yaitu : Kulit tanpa dicabut bulunya

Kulit dicabut bulunya

Kulit diberi abu gosok sebelum dicabut bulunya. Hal ini dimaksudkan untuk mempermudah pencabutan bulu dengan tujuan agar kulit tidak rusak.

Kulit itik yang dikuliti tanpa melalui pencabutan bulu langsung diawet dean garam, selanjutnya di proses yang diawali dengan perendaman kemudian agapuran.

nurut Purnomo Eddy, 1991, tujuan pengapuran adalah untuk membengkakkulit, melarutkan protein dan membersihkan lemak. Sedangkan Natrium fida herfungsi untuk merontokkan bulu yang melekat pada kulit. la proses pengapuran, menurut Basalamah Hasan, 1993, menggunakan $300 \%$

Majalah Barang Kulit, Karet dan Plastik air, $2,5 \% \mathrm{Ca}(\mathrm{OH})_{2}$ dan $1 \% \mathrm{Na} 2 \mathrm{~S}$ kemudian diputar selama 20 jam. Pada pengapuran ini pengadukan dilakukan selama 5 menit lalu didiamkan selama 1 (satu) jam, diaduk lagi dan seterusnya. Pengapuran tersebut dilakukan sampai 3 kali, pada pengapuran yang ke III atau pengapuran ulang, dilakukan bersama-sama dengan pengikisan protein dan pembuangan lemak I, kemudian pembuangan lemak diulangi sekali lagi setelah pengasaman selesai.

Tujuan dari penelitian ini adalah untuk mendapatkan kulit itik yang utuh dan dapat dimanfaatkan semaksimal mungkin.

\section{MATERI DAN METODA}

Penelitian ini menggunakan 24 ekor itik yang terdiri dari 12 ekor itik ter kurung dan 12 ekor itik gembala, yang diberi 3 perlakuan yaitu :

- 4 ekor itik terkurang, tanpa cabut bulu

- 4 ekor itik gembala, tanpa cabut bulu

- 4 ckor itik terkurung, dicabut bulunya

- 4 ekor itik gembala, dicabut bulunya.

- 4 ekor itik terkurung, diberi abu sebelum dicabut bulunya

- 4 ekor itik gembala, diberi abu sebelum dicabut bulunya

Kulit-kulit tersebut diproses sampai finis kemudian diuji kckuatan tarik dan uj secara organoleptis mengenai kerusakan kulitnya.

\section{PELAKSANAAN PENELITIAN}

Dalam penelitian ini pelaksanaan pemotongan sampai pengulitan dilaku kan di peternak atau penjual itik. Proses pengukitan kulit itik adalah sebagai berikut : Pertama kali itik dipotong sampai darah keluar sebanyak-banyaknya, kemudian diantara daging dan kulit pada bagian leher dimasukkan selan kemudian dipompakan udara kedalamnya dengan maksud untuk mempermudah pengulitan, dan pengulitan ini dilakukan dengan cara pembelahan pada bagian punggung.

- Untuk perlakuan tanpa cabut bulu, kulit langsung dikuliti.

- Untuk perlakuan dengan cabut bulu, sebelum dikuliti, bulu-bulu yang terda pat dikulit dicabut secara hati-hati.

- Untuk perlakuan kulit yang diberi abu gosok, sebelum dikuliti, kulit ditabur dengan abu gosok sampai merata di seluruh bagian badan itik sampai ke le her, kemudian baru dicabut bulunya.

Vol. IX No. 17 Tahun 1993/1994 
Setelah proses pengulitan sclesai selanjutnya kulit diawet dengan garam istal scbanyak $25 \%$ dari berat kulit, dan scbelum digaram kulit dicuci dan clup dalam Hide Poison 0,5\% sclama kurang lebih 5 menit (Untari S, 1993). lanjutnya kulit diproses di BBKKP sampai finish kemudian kulit diuji secara ganoleptis mengenai kerusakan kulit dan diuji sifat fisisnya mengenai keatan tariknya. Hasil uji kekuatan tarik dianalisa dengan metode statistik RBD ("Completed Randomized Block Design").

\section{IIASIL PENELITIAN DAN PEMBAIIASAN}

\section{i Organoleptis.}

Hasil uji organoleptis dapat dipcriksa pada tabel 1. Hasil uji organoleptis lit itik, yang terdapat pada lampiran. Pengamatan dilakukan mulai dari kulit cpas dari hewannya, yang meliputi kerusakan akibat pencabutan bulu. Pencatan bulu apabila dilakukan kurang hati-hati maka akan mengakibatkan kerukan kulit, demikian juga pada proses pengulitannya (Untari S, 1990).

uri tabel 1. dapat diketahui bahwa :

Kulit yang dicabut bulunya, rata-rata kerusakannya 5\%

Kulit yang dicabut bulunya dengan diberi abu gosok, rata-rata kerusakannya $5 \%$

Kulit yang dikuliti tanpa pencabutan bulu, rata-rata kerusakannya $1 \%$ hampir semuanya utuh dalam arti tidak ada yang sobek.

Kulit yang dicabut bulunya sctelah pengulitan ditinjau dari tingkat kerukannya, rata-rata $5 \%$, hal ini akan mempengaruhi kualitas kulit dan besarnya Isan kulit yang dapat dimanfaatkan. Bila kulit yang masih segar sudah banyak rusakannya maka akan mempengaruhi mutu pada kulit jadinya. Olch karena dalam pencabutan bulu hendaknya dilakukan secara hati-hati. i Fisis.

Hasil uji fisis ditinjau dari kekuatan tarik kulit itik dapat diperiksa pada el 2. Rata-rata Hasil Uji Kekuatan Tarik Kulit Itik yang terdapat pada lamran 2. Uji kekuatan tarik dilakukan pada bagian lẹcer, punggung dan perut, sil uji merupakan nilai/harga rata-rata. Analisa várian menunjukkan bahwa . lak ada bedanyata baik pada cara pengulitan maupun pemeliharaan $(\mathrm{P} \leq 0,05)$ itu pada kulit tanpa cabut bulu, cabut bulu maupun cabut bulu dengan abu sok. Demikian pula pada itik terkurang maupun gembala.
Pemanfaatan Itik.

Itik selain dimanfaatkan telur, daging dan kulitnya, ternyata bulunya dapat dimanfaatkan untuk "bedding" atau sebagai bahan pengisi perlengkapan tidur seperti "sleeping bag" (kantong tidur) selimut, bantal dan bahan pengisi jaket. Prospek industri bulu itik sangat cerah, bahkan perusahaan pengelahan bulu itik di negara-negara Industri di Asia terus menerus mencari bahan baku (Raharjo, Yono C, 1990),

Dari hasil analisa varian menunjukkan bahwa antara kulit yang dicabut bulunya, kulit yang dicabut bulunya dengan diberi abu gosok dan dengan kulit yang dikuliti tanpa pencabutan bulu tidak ada beda nyata. Mengingat hal tersebut diatas maka agtar kulit itik dapat dimanfaatkan semaksimal mungkin maka sebaiknya sebelum dikuliti dicabut bulunya dengan hati-hati kemudian baru diproses, sehingga diperoleh nilai tambah ternak itik dari pemanfaatan bulunya, selain tclur, daging dan kulit.

\section{KESIMPULAN}

Dari hasil penelitian ini dapat disimpulkan bahwa :

1. Pencabutan bulu setelah pengulitan akan menyebabkan kerusakan kulit ratarata $5 \%$.

2. Dari uji kekuatan tarik ternyata tidak ada beda nyata antara kulit yang dicabut bulu, kulit yang dicabut bulu dengan diberi abu gosok dan kulit tanpa dicabut bulu.

3. Bulu itik dapat dimanfaatkan sebagai bahan baku untuk pengisi jaket, "bedding $^{n}$ atau pengisi perlengkapan tidur dan lain-lain, yang berarti akan memberi nilai tambah dari ternak itik.

4. Untuk mendapatkan kulit yang utuh, maka pencabutan bulu dilakukan secara hati-hati dan memerlukan ketrampilan serta latihan.

\section{SARAN}

Untuk mendapatkan kulit itik yang utuh perlu dilakukan pencabutan bulu secara hati-hati sebelum pengulitan. 


\section{DAFTAR PUSTAKA}

Basalamah Hasan dkk, 1993, Penelitian Pengaruh Jenis Bahan Penyamak terhadap Sifat Fisis Kulit Itik, Procecding Pertemuan Teknis Industri Penyamakan Kulit Tingkat Nasional 1993, Balai Besar Penclitian dan Pengembangan Industri Barang Kulit, Karet dan Plastik, Yogyakarta.

Djojowidagdo S, 1988, Kulit Kerbau Jantan, Sifat-sifat dan Karakteristiknya Sebagai Bahan Wayang Kulit Purwo, Desertasi SI Universitas Gadjah Mada.

Oetojo Bambang, dkk, 1990, Penelitian Pendahuluan Proses Penyamakan Kulit Itik, Procecding Pengembangan Usaha Ternak Itik di Jawa Tengah, Sub Balai Penelitian Ternak Ungaran.

Purnomo Eddy, 1991, Penyamakan Kulit Reptil, Percetakan Kanisius Yogyakarta.

Rahardjo, Yono C, 1990, Prospek dan Kendala Dalam Industri Bulu Itik di Indonesia, Proccedings Temu Tugas Sub Sektor Peternakan Pengembangan Usaha Ternak Itik di Jawa Tengah, Sub Balai Penelitian Ternak, Klepu.

oebijarso K, 1990, Pemanfaatan Kulit Itik Untuk Industri Barang Kulit, Procecdings Temu Tugas Sub Scktor Peternakan Sub Balai Penelitian Ternak, Klepu.

Untari S, dkk, 1990, Penelitian Pendahuiuan Mutu Kulit Jadi dari Itik Lokal, Proceedings Temu Tugas Sektor Peternakan, Sub Balai Penelitian Ternak, Klepu.

Jntari S, Wiluto D, 1990, Penelitian Penyamakan Kulit Itik dengan Garam Krom, Makalah pada Seminar Himpunan Kimia Indonesia, Cabang Daerah Istimewa Yogyakarta, 12 Mei 1990 di Fakultas Farmasi UGM.

Jntari S, dkk, 1993, Penelitian Cara Pengawetan Kulit Itik Untuk Disamak, Proceedings Pertemuan Teknis Industri Penyamakan Kulit Tingkat Nasional 1993, Balai Besar Penelitian dan Pengembangan Industri Barang Kulit, Karet dan Plastik, Yogyakarta.
Lampiran 1. Uji Organoleptis kerusakan kulit itik setelah pengulitan.

\begin{tabular}{c|c|r|r}
\hline No. & Tanpa cabut bulu & Cabut bulu & Cabut bulu dengan abu \\
\hline 1. & Utuh $(0 \%)$ & $6 \%$ & Utuh $(0 \%)$ \\
2. & $1 \%$ & $5 \%$ & $1 \%$ \\
3. & Utuh $(0 \%)$ & Utuh $(0 \%)$ & Utuh $(0 \%)$ \\
4. & Utuh $(0 \%)$ & $12 \%$ & $15 \%$ \\
5. & Utuh $(0 \%)$ & $3 \%$ & Utuh $(0 \%)$ \\
6. & Utuh $(0 \%)$ & Utuh $(0 \%)$ & $5 \%$ \\
7. & $1 \% \%$ & $4 \%$ & $8 \%$ \\
8. & Utuh $(0 \%)$ & $10 \%$ & \\
\hline
\end{tabular}

Lampiran 2. Rata-rata hasil uji kekuatan tarik kulit itik

\begin{tabular}{l|c|c|c}
\hline \multirow{2}{*}{ Pemeliharaan } & \multicolumn{3}{|c}{ Cara Pengulitan } \\
\cline { 2 - 4 } & Tanpa cabut bulu & Cabut bulu & $\begin{array}{c}\text { Cabut bulu dengan } \\
\text { ahu. }\end{array}$ \\
\hline \multirow{5}{*}{ Terkurung } & 44,577 & 38,553 & 53,746 \\
& 42,580 & 51,256 & 58,027 \\
& 42,810 & 52,156 & 72,267 \\
& 43,656 & 47,321 & 61,346 \\
\hline \multirow{5}{*}{ Gembala } & 36,986 & 58,043 & 51,453 \\
& 30,410 & 66,566 & 39,523 \\
& 42,550 & 80,786 & 57,223 \\
& 36,649 & 68,465 & 49,400 \\
\hline
\end{tabular}

